\title{
Benefit of Gene Expression Profiling in Gastrointestinal Neuroendocrine Tumors of Unknown Primary Origin
}

\author{
JAMES J. SALLER ${ }^{1}$, MINTALLAH HAIDER ${ }^{2}$, SAMEER AL DIFFALHA ${ }^{1}$ and DOMENICO COPPOLA ${ }^{1,3}$ \\ ${ }^{1}$ Department of Pathology, Moffitt Cancer Center and Research Institute, Tampa, FL, U.S.A.; \\ ${ }^{2}$ Department of Gastro-intestinal Oncology, Moffitt Cancer Center and Research Institute, Tampa, FL, U.S.A.; \\ ${ }^{3}$ Department of Pathology, Florida Digestive Health Specialists, Bradenton, FL, U.S.A.
}

\begin{abstract}
Background/Aim: Cancer of unknown primary $(C U P)$, representing 3-5\% of all newly diagnosed cancers in the United States, is a presumptive, non-definitive diagnosis rendered when a primary tumor site cannot be identified after exhaustive diagnostic evaluation, including cases of neuroendocrine neoplasms (NENS). CUPs are characterized by findings that are challenging to reconcile, including inconclusive immunohistochemical (IHC) stains, an undifferentiated morphologic phenotype, history of multiple cancers, a clinical presentation that is discordant from histologic findings, an atypical distribution of metastases, or lack of expected response to treatment. For a significant subset of NENs (10\%), traditional diagnostic evaluation is unable to determine a primary tumor site using histomorphology and IHC stains. Gene expression profiling (GEP) of either mRNA or microRNA is the technique utilized in the three commercially available platforms that provide a prediction of tumor type in cases of diagnostic uncertainty of CUPs, including those with neuroendocrine differentiation. Case Series Report: Here we present four cases of NENs, where the diagnosis based upon histomorphological and IHC features presented a unique challenge that ultimately benefited from the integration of molecular tumor classification using the validated assay. CancerTYPE ID by Biotheranostics is based on a quantitative RT-PCR assay that
\end{abstract}

Correspondence to: Domenico Coppola, MD, 11505 Palmbrush Trail, Suite 120, Lakewood Ranch, FL 34202, U.S.A. Tel: +1 9417574800 ext 308, Fax: +1 9417574803, e-mail: Domenico.Coppola@fdhs.com

Key Words: Cancer unknown primary, neuroendocrine, gene expression profiling, RT-PCR.

This article is an open access article distributed under the terms an conditions of the Creative Commons Attribution (CC BY-NC-ND) 4.0 international license (https://creativecommons.org/licenses/by-nc-nd/4.0), uses a computational algorithm to measure the collective expression of 92 genes (87 cancer-related genes and 5 control genes). This case series reports five appropriate clinical scenarios that highlight the utility of a GEP-based assay to effectively provide a molecular tumor classification to identify NEN subtypes and tumor primary site of origin. Conclusion: These cases demonstrated that the CancerTYPE ID test was able to resolve challenging diagnoses for primary and metastatic NENs. These cases emphasize the clinical need of utilizing a GEP-based assay for determining the anatomic site of origin and NEN subtyping, both essential for the appropriate clinical management of NENs.

Cancer of unknown primary (CUP; $3-5 \%$ of all newly diagnosed cancers in the United States) is a presumptive, non-definitive diagnosis rendered when a primary tumor site cannot be identified after exhaustive diagnostic evaluation (1-3). CUPs are characterized by findings that are challenging to reconcile, including inconclusive immunohistochemistry (IHC) stains, an undifferentiated morphologic phenotype, history of multiple cancers, a clinical presentation that is discordant from histologic findings, an atypical distribution of metastases, or a lack of expected response to treatment (1). Gene expression profiling (GEP) of either mRNA or microRNA is the technique utilized in the three major commercially available platforms that provide a molecular prediction of tumor type in cases of diagnostic uncertainty and CUPs, including CUPs with neuroendocrine differentiation $(1,4-6)$.

Neuroendocrine tumors (NETs) are graded depending on their mitotic rate. The high-grade (poorly differentiated) tumors are referred to as neuroendocrine carcinomas (NECs), which occur at a significantly lower frequency than NETs. NECs usually present with metastatic disease and portend a worse prognosis. There are few reliable prognostic factors that demonstrate clinical utility with this type of tumors.

For a significant subset of NENs (10\%), traditional diagnostic evaluation is unable to determine a primary tumor 
site using histomorphological tests and immunohistochemistry (IHC) (7). Regardless of anatomic site of origin, observation of exclusively large cell features, increased mitotic count and a high Ki-67 proliferation index are associated with unfavorable outcomes, whereas microsatellite instability (MSI) is associated with favorable outcomes (8-11). Determination of the anatomic site of origin as well as the grade and level of differentiation of NENs are important regarding guidance of clinical management. There are cases where, despite exhaustive work up, there is still ambiguity and GEP may help in determining the site of origin and/or grade.

Recent molecular investigations are bringing more clarity to the genomic profiles in NETs and NECs (12-17). A study using a combination of whole genome and targeted exome sequencing demonstrated similarity between the genomic profiles of large and small cell pancreatic NECs, which were distinct from well differentiated pancreatic neuroendocrine tumors (PNETs) (14). This same study of small cell and large cell PNECs reported alterations in the $\mathrm{p} 53$ and the Rb/p16 pathways, as well as BCL2 overexpression, which were not dysregulated in PNETs. PNETs had genomic alterations (GAs) causing dysregulation in genes involved with chromatin remodeling, such as MEN1, DAXX and ATRX, genes involved with DNA damage repair and telomere maintenance, and genes in the PI3K/Akt/mTOR pathway (14). Although loss of PTEN, ATRX and DAXX expression are characteristic of lower grade PNETs, their loss may carry a worse prognosis (14). Moreover, GEP of PNETs identified a subgroup associated with HIF signaling (18). PNETs have also been reported to upregulate epithelial mesenchymal transition (EMT) by signaling involving SLUG, through increased expression of the cancer stem cell marker DCLK1 as well as Cathepsin Z (19-21). PNECs have similarly been shown to upregulate EMT, however the mechanism of EMT upregulation observed in PNECs has been reported to involve a relative decrease in expression of the adhesion molecules, a relative decrease in E-cadherin/ $\beta$-catenin complex integrity and a relatively higher expression of transcriptional repressors (Snail1, Snail2, Twist and Foxc2) when compared with PNETs (22-24). NETs and NECs have been shown to differ in terms of biologic behavior and responsiveness to different therapies, based on GEP and types of GAs that are oncogenic drivers, when compared to other NETs and NECs from different anatomic sites of origin (8-14, 17, 18, 25-82).

Evaluation by histomorphology and IHC may be of significant value in confirming neuroendocrine differentiation for the majority of cases. However, being solely reliant on histomorphology of a limited number of lineage markers such as CDX-2, PDX-1, NESP-55, TTF-1 and PAX8 presents challenges in definitively determining the NEN subtype $(43,62)$.

A straight-forward diagnosis may become further complicated by the possibility of considering mixed neuroendocrine-nonneuroendocrine neoplasms (MiNENs), which is an entity found throughout the gastrointestinal tract (83-88). Identification of a non-neuroendocrine component is important in distinguishing NEC from MiNEN, while intratumoral heterogeneity may present a challenge in definitively determining whether a tumor is composed of at least $30 \%$ neuroendocrine and nonneuroendocrine component.

Efforts to utilize IHC to evaluate NENs prognostically have reported results that do not warrant mainstream use to inform clinical decision-making. Preliminary studies initially supported the role of CD117 and Cytokeratin 19 (CK19) as potential biomarkers with utility as poor prognostic factors $(45,89)$. However, further studies demonstrated inter-study variability regarding the association of CD117 and CK19 with prognosis; thus, further investigation should be performed in order to accurately assess the utility of CD117 and CK19 as potential metrics as prognostic biomarkers $(17,45,49,89)$. Interestingly, in a study of 109 patients with gastroenteropancreatic neuroendocrine carcinoma (GEP-NEC), multivariate analysis demonstrated that elevated lactate dehydrogenase (LDH) and aspartate aminotransferase (AST) were factors that were significantly associated with unfavorable prognosis and were determined to be more useful than histomorphological markers (44). With the paucity of available clinical data for prospective IHC-based and serological prognostic biomarkers, reliable GEPbased assays would significantly facilitate the clinical management of NENs.

GEP is an effective adjunctive means of prognostic assessment in the assignment of probability of subtype categories that represent lower-grade NENs (carcinoids) as well as higher-grade NECs (small cell carcinomas and large cell carcinomas). Their grade and level of differentiation also carries treatment implications (12). GEP is an effective method in determining the anatomic site of origin, which is important in determining the grading and staging of NENs $(63,74,90-95)$.

Here we present four cases of NENs, where the diagnosis based upon histomorphological and IHC features presented a unique challenge that ultimately benefited from the integration of molecular tumor classification using CancerTYPE ID ${ }^{\circledR}$. CancerTYPE ID ${ }^{\circledR}$ (Biotheranostics, San Diego, CA, USA) is a validated assay based on quantitative RT-PCR assay that uses a computational algorithm to measure the collective expression of 92 genes (87 cancerrelated genes and 5 control genes) and a reference database of more than 2,000 well characterized tumors to classify a tumor sample into 28 different main tumor types and 50 tumor sub-types. In cases where imaging, pathological workup including IHC $(83,96-98)$, and other diagnostic tests are unable to identify the NEN subtype, molecular tumor classification by CancerTYPE ID ${ }^{\circledR}$ has shown particular utility in correctly classifying the NENs with obvious impact on patient therapy. Furthermore, we propose a diagnostic algorithm that incorporates molecular tumor classification for NEN subtyping and anatomic primary site identification. 
Table I. Antibodies used for immunohistochemistry analysis.

\begin{tabular}{|c|c|c|c|c|c|}
\hline Antibody & Vendor & Catalog \# & Dilution & Antigen retrieval & Positive control \\
\hline MOC31 & Cell Marque & $284 \mathrm{M}-16$ & $1: 10$ & $\mathrm{CCI}$ & Colon adenocarcinoma \\
\hline ATRX & Sigma & HPA001906 & $1: 800$ & $\mathrm{CCI}$ & Astrocytoma \\
\hline CD117 YR145 & Cell Marque & 117R-16 & $1: 400$ & CCI & GIST \\
\hline Synaptophysin sp11 & VMS & $790-4407$ & RTU & $\mathrm{CCI}$ & NET GI \\
\hline Chromogranin LK2H10 & Cell Marque & $238 \mathrm{M}$ & $1: 100$ & $\mathrm{CCI}$ & NET GI \\
\hline AE1/AE3 & VMS & $760-2135$ & RTU & PI-12 & Normal Liver \\
\hline S100 Polyclonal & DAKO & 20311 & $1: 250$ & None & Melanoma \\
\hline HMB45 & HMB NC & NCL-HMB45 & $1: 2$ & $\mathrm{CCI}$ & Melanoma \\
\hline Ki-67 30-9 & VMS & $790-4286$ & RTU & CCI & Tonsil \\
\hline p53 BP53-11 & VMS & $760-2542$ & RTU & $\mathrm{CCI}$ & Breast Cancer \\
\hline TTF-1 8G7G3/1 & DAKO & M3575 & $1: 50$ & CCI & Thyroid normal \\
\hline BRAF V600 VE1 & VMS & $790-4855$ & RTU & CCI & BRAF mutated colon cancer \\
\hline CAM5.2 & CAM 5.2 BD & 349205 & RTU & CCI & Normal colon \\
\hline GFAP EP672V & VMS & $750-4345$ & RTU & CCI & Brain normal \\
\hline Vimentin BB4 & VMS & $760-2512$ & RTU & CCI & Skin \\
\hline IDH1 R132HH09 & Dianova & DIA-09 & $1: 20$ & CCI & Oligodendroglioma \\
\hline Pan keratin AE1/AE3/PCK 26 & VMS & $760-2135$ & RTU & PI-12 & Normal liver \\
\hline
\end{tabular}

RTU: Ready to use; CCI: cell conditioning 1; PI-12: protease inhibitor $12 \mathrm{~min}$.

\section{Case Series Report}

Case selection and pathological evaluation. The objective of this retrospective study was to identify cases of metastatic neuroendocrine neoplasms (NENs) where molecular tumor classification by the 92-gene assay was used to reach the final diagnosis and likely impacted patient treatment. An initial review of clinical cases undergoing pathological evaluation for metastatic NEN identified at least four cases where integration of the 92-gene assay CancerTYPE ID ${ }^{\circledR}$ (Biotheranostics Inc.) significantly contributed to the final diagnosis. Pathological evaluation for NEN included a review of the clinical case history, histomorphological examination of biopsy material and immunohistochemical (IHC) analysis using protocols that are standardized within the CLIAcertified, CAP-accredited laboratory within the Department of Pathology at Moffitt Cancer Center. Information on the antibodies used for IHC can be found in Table I. Molecular tumor classification by CancerTYPE ID ${ }^{\circledR}$ was ordered as part of the diagnostic work up for these cases.

CancerTYPE ID ${ }^{\circledR}$ testing. Formalin fixed paraffin embedded (FFPE) tumor blocks were shipped to Biotheranostics, a CLIA-certified, CAP-accredited laboratory to perform molecular tumor classification using CancerTYPE ID ${ }^{\circledR}$. CancerTYPE ID ${ }^{\circledR}$ consists of a standardized laboratory workflow where the sample undergoes histological evaluation based on $\mathrm{H} \& \mathrm{E}$ staining by a board-certified pathologist to designate tumor regions for enrichment by laser microdissection. Total RNA collected from tumor- enriched cells served as the input for the 92-gene RT-PCR assay, a validated gene expression-based classifier that uses a pre-specified computational algorithm that applies linear discriminant analysis to generate probabilities for candidate tumor types based on the degree of similarity of the queried sample to the reference tumor database (99). The assay classifies 50 different tumor types and tumor subtypes from 105 different morphologies. The CancerTYPE ID ${ }^{\circledR}$ test report is structured as a two-level labeling scheme: A Main Tumor Type (i.e., Neuroendocrine) and a second tier Tumor Subtype (i.e., Small/large cell lung carcinoma). In some cases, additional main tumor type(s) with $\geq 5 \%$ probability are included in the test report as rule-in tumor type(s) with lower probabilities. Tumor types with a combined probability of $<5 \%$ that can be ruled out with $95 \%$ confidence are also included (i.e., rule-out tumor types).

\section{Patient 1}

Clinical presentation, imaging, and surgical intervention. An 84-year-old woman presented to the hospital with severe anemia of uncertain etiology. Initial chest and abdominal CT scan showed a lung node as well as several hepatic lesions. A liver core biopsy obtained suggested an initial interpretation of spindle cell neoplasm, favoring Gastrointestinal Stromal Tumor (GIST) based on spindle features and CD117 positivity.

Pathology evaluation. Evaluation of $\mathrm{H} \& \mathrm{E}$ sections at Moffitt Cancer Center described a neoplasm composed of spindle cells with a high nuclear-cytoplasmic (N/C) ratio, 

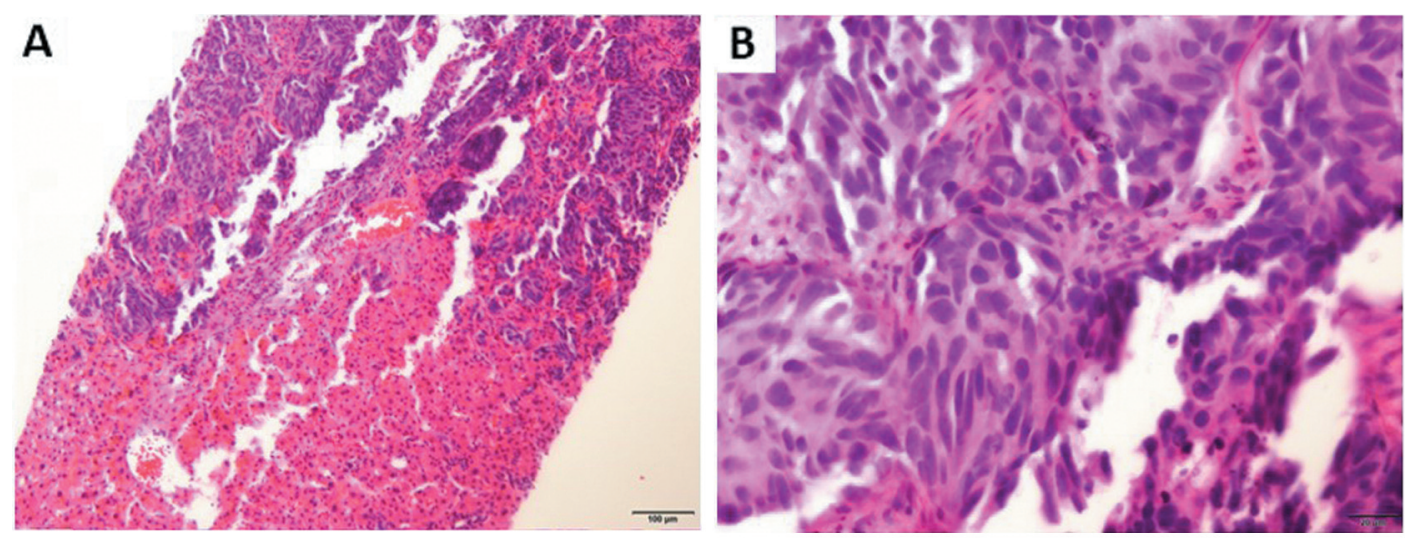

Figure 1. Liver biopsy of the neoplasm predominantly composed of spindle cells in Patient 1. (A) Low power view illustrating areas of tumor necrosis. (B) High power view illustrating spindle morphology with a high N/C ratio.

abundant mitoses and tumor necrosis (Figure 1A). Considerations in the differential diagnosis included spindle cell tumors (leiomyosarcoma, GIST), melanoma, spindle cell carcinoma of the lung and NET. To further narrow the wide differential diagnosis, additional IHC was performed. Tumor cells stained positive for MOC31, CD117, synaptophysin, chromogranin and AE1/AE3, but negative for S100 and HMB45. Of note, CD117 has been shown to be positive in a subset of colorectal NETs (Figure 2B and Table I) (42). Ki67 staining demonstrated a $15-20 \%$ proliferation index, which is at the upper end for an intermediate Grade 2 tumor. Whereas the IHC profile is consistent with a NET, the lack of protein markers for NET subtypes combined with the clinical presentation of metastatic disease limited further NET subtyping by immunomorphology alone.

Molecular tumor classification by CancerTYPE ID ${ }^{\circledR}$. FFPE tissue from the liver biopsy was submitted to Biotheranostics for testing with the CancerTYPE ID ${ }^{\circledR}$ platform. Within 5 days of receiving the tissue, Biotheranostics returned the CancerTYPE ID ${ }^{\circledR}$ report that indicated a Main Tumor Type of Neuroendocrine (96\% probability) and a Main Tumor Subtype of lung carcinoid (Table II). The other NET subtypes reported by CancerTYPE ID $^{\circledR}$ (Merkel cell carcinoma, Small/Large cell carcinoma, GI carcinoid and Islet cell carcinoma) have a combined probability of $<5 \%$ but cannot be statistically excluded.

Impact of molecular tumor classification and treatment. In the context of the patient's history of a lung mass with multiple liver lesions, the results of the tumor's GEP helped to inform the diagnosis, which was determined to be a welldifferentiated (grade 2) NET originating from the lung. This result guided therapy and impacted this patient's outcome.

\section{Patient 2}

Clinical presentation, imaging, and surgical intervention. A 67-year-old male smoker with a history of hypertension, hyperlipidemia and peripheral vascular disease presented to the hospital Emergency Department for right-sided numbness and tremors, with occasional loss of motor control in recent weeks. A head CT demonstrated a low-density lesion in the inferior left thalamus, extending into the left cerebral peduncle with surrounding vasogenic edema. An MRI of the brain illustrated left-sided dural enhancement, with a $1 \mathrm{~cm}$ uniformly enhancing nodule in the anterior right temporal lobe, and a second $1.7 \times 1.2 \mathrm{~cm}$ lesion with central necrosis at the juncture of the left thalamus and left cerebral peduncle. A CT scan of the chest, abdomen and pelvis showed no evidence of metastatic disease or suspicious adenopathy, with a non-contributory medical history. Resection of the right temporal lobe lesion for tissue diagnosis was performed 3 days later, as well as metastatic work up to obtain an accurate diagnosis and guidance for adjuvant treatment.

Pathology evaluation. Intraoperative evaluation demonstrated highly cellular sheets of a patternless neoplasm with abrupt borders, with mildly reactive brain and subtle infiltration. The neoplastic cells had scant eosinophilic cytoplasm with indiscernible borders and irregular hyperchromatic nuclei lacking nucleoli, with frequent mitoses (12 in a single High Power Field) (Figure 2). Immunohistochemical analysis demonstrated that the tumor cells stained mildly positive for CAM5.2, had strong uniform nuclear staining for TTF1, and weak inconsistent vimentin and pan-keratin positivity (Table I). Tumor cells were negative for CK7 and CK20. Synaptophysin highlighted normal brain, and at the tumorbrain interface there was delicate granular positivity extending between clusters of tumor cells. GFAP was 
Table II. Summary of cases with their evaluation.

\begin{tabular}{|c|c|c|c|c|}
\hline & Case 1 & Case 2 & Case 3 & Case 4 \\
\hline $\begin{array}{l}\text { Diagnostic challenge } \\
\text { before IHC }\end{array}$ & $\begin{array}{l}\text { Further characterize the spindle } \\
\text { cell tumor (leiomyosarcoma, } \\
\text { GIST, carcinoma of lung). } \\
\text { Other possibilities } \\
\text { (Melanoma and NET). }\end{array}$ & $\begin{array}{l}\text { Further characterize a newly } \\
\text { discovered brain neoplasm }\end{array}$ & $\begin{array}{l}\text { Further characterize newly } \\
\text { discovered blue round cell } \\
\text { neoplasm in a soft } \\
\text { tissue mass }\end{array}$ & $\begin{array}{l}\text { Further characterize } \\
\text { a liver biopsy of } \\
\text { unknown primary. }\end{array}$ \\
\hline IHC stains* & $\begin{array}{c}\text { CD117+ } \\
\text { Chromogranin+ } \\
\text { AE1/AE3+ } \\
\text { MOC31+ } \\
\text { Synpatophysin+ } \\
\text { S100- } \\
\text { HMB45- }\end{array}$ & $\begin{array}{c}\text { ATRX+ } \\
\text { CAM5.2+ } \\
\text { GFAP+ (Scattered) } \\
\text { P53+ } \\
\text { SMARCB1+ } \\
\text { Synaptophysin+ } \\
\text { TTF1+ (Strong, uniform) } \\
\text { Pan-cytokeratin+ (Weak) } \\
\text { Vimentin+ (Weak) } \\
\text { BRAF-V600E- } \\
\text { CK7- } \\
\text { IDH1-R132H- }\end{array}$ & $\begin{array}{c}\text { Synaptophysin+ (diffuse) } \\
\text { Chromogranin+ (focal) } \\
\text { Ki-67+ (80\%) } \\
\text { AE1/AE3/CAM5.2- } \\
\text { CEA (polyclonal)- } \\
\text { CK7- } \\
\text { CK20- } \\
\text { CD99- } \\
\text { KER903- } \\
\text { TTF-1- } \\
\text { Desmin- } \\
\text { Actin- } \\
\text { CD45- } \\
\text { S-100- } \\
\text { Bcl-2- }\end{array}$ & $\begin{array}{c}\text { AE1/AE3+ (focal) } \\
\text { CAM5.2+ (focal) } \\
\text { OSCAR+ (faint) } \\
\text { INI-1+ (retained) } \\
\text { Ki-67+ }(>80 \%) \\
\text { Synaptophysin- } \\
\text { Chromogranin- } \\
\text { CD99- } \\
\text { KER903- } \\
\text { Glypican-3- } \\
\text { Arginase- } \\
\text { ERG- } \\
\text { CD34- } \\
\text { p40- } \\
\text { p63- } \\
\text { CK5/6- } \\
\text { CK7- } \\
\text { CK20- } \\
\text { PAX8- } \\
\text { KER903- } \\
\text { TTF-1- } \\
\text { GATA3- } \\
\text { Hep-Par-1- } \\
\text { CD45- } \\
\text { S-100- } \\
\text { CD56- } \\
\text { INSM1- }\end{array}$ \\
\hline $\begin{array}{l}\text { Diagnostic challenge } \\
\text { after IHC }\end{array}$ & $\begin{array}{l}\text { Neuroendocrine tumor } \\
\text { of unknown subtype }\end{array}$ & $\begin{array}{l}\text { Differential diagnosis of glioma } \\
\text { or neuroendocrine carcinoma }\end{array}$ & $\begin{array}{l}\text { IHC results were non- } \\
\text { contributory for } \\
\text { determination of } \\
\text { primary anatomic site. }\end{array}$ & $\begin{array}{l}\text { Neuroendocrine IHC } \\
\text { results were negative } \\
\text { and non-contributory } \\
\text { for determination of } \\
\text { primary anatomic site. }\end{array}$ \\
\hline $\begin{array}{l}\text { CancerTYPE ID } \\
\text { Result } \\
\text { Main type** } \\
\text { Main subtype }\end{array}$ & $\begin{array}{l}\text { Neuroendocrine }(96 \%) \\
\text { Lung carcinoid }(96 \%)\end{array}$ & $\begin{array}{l}\text { Neuroendocrine }(96 \%) \\
\text { Small/large cell lung } \\
\text { carcinoma }(96 \%)\end{array}$ & $\begin{array}{c}\text { Neuroendocrine }(96 \%) \\
\text { Small/large cell lung } \\
\text { carcinoma }(63 \%) \\
\text { Merkel cell } \\
\text { carcinoma }(33 \%)\end{array}$ & $\begin{array}{c}\text { Neuroendocrine (90\%) } \\
\text { Small/large cell lung } \\
\text { carcinoma }(90 \%)\end{array}$ \\
\hline Final diagnosis & $\begin{array}{l}\text { Well-differentiated } \\
\text { (grade 2) } \\
\text { NET originating } \\
\text { from the lung. }\end{array}$ & $\begin{array}{c}\text { Small/large cell } \\
\text { neuroendocrine } \\
\text { carcinoma of the lung. }\end{array}$ & $\begin{array}{c}\text { Small/large cell } \\
\text { neuroendocrine } \\
\text { carcinoma of the lung. }\end{array}$ & $\begin{array}{c}\text { Small/large cell } \\
\text { neuroendocrine } \\
\text { carcinoma of the lung. }\end{array}$ \\
\hline
\end{tabular}

*+ represents tumor cells with positive staining. - represents tumor cells with no expression. **Main type and main subtype are specified with the probability of diagnosis $(\%)$.

expressed in scattered neoplastic cells, as well as in reactive astrocytes. Nuclear p53 overexpression was noted in approximately $50 \%$ of tumor cell nuclei, and Ki-67 demonstrated a proliferative index of $60 \%$. Mutant IDH1R132H and BRAFV600E were both negative; and retained expression was observed for both ATRX and INI1 


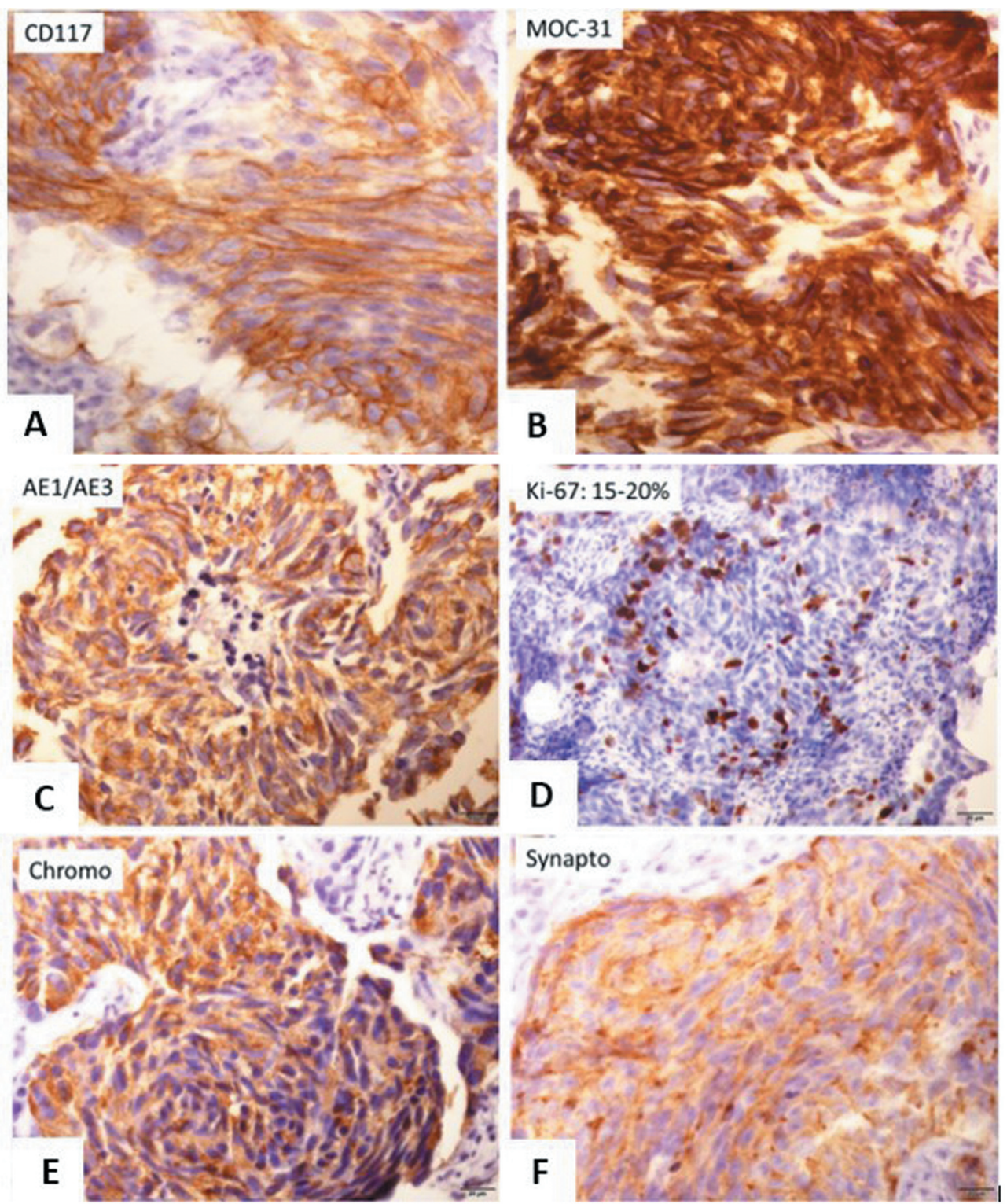

Figure 2. Immunohistochemical (IHC) staining for Patient 1. The tumor cells are positive for CD117, MOC31, AE1/AE3, chromogranin and synaptophysin. Ki67 staining demonstrates a proliferation index of $15-20 \%$.

(SMARCB1) (Table I, Figure 3). The observed tumor histomorphology and inconclusive IHC stains in this case presented the possibility of either a glioma or a NEC that could not be further classified.

Molecular tumor classification by CancerTYPE ID ${ }^{\circledR}$. FFPE tissue from the brain biopsy was submitted to Biotheranostics for testing with the CancerTYPE ID ${ }^{\circledR}$ platform. Within 4 days of receiving the tissue, Biotheranostics returned the CancerTYPE ID ${ }^{\circledR}$ report that indicated a main tumor type of neuroendocrine $(96 \%$ probability) and a main tumor subtype of small/large cell lung carcinoma (Table I). The other NET subtypes reported by CancerTYPE ID ${ }^{\circledR}$ (Merkel cell carcinoma, Small/Large cell carcinoma, GI carcinoid and Islet cell carcinoma) have a combined probability of $<5 \%$ but cannot be statistically excluded. Importantly, CancerTYPE ID ${ }^{\circledR}$ ruled out brain as a possible main tumor type with $95 \%$ confidence.

Impact of molecular tumor classification and treatment. Based on the patient's clinical history histological analysis including positive TTF-1 staining, the molecular tumor 

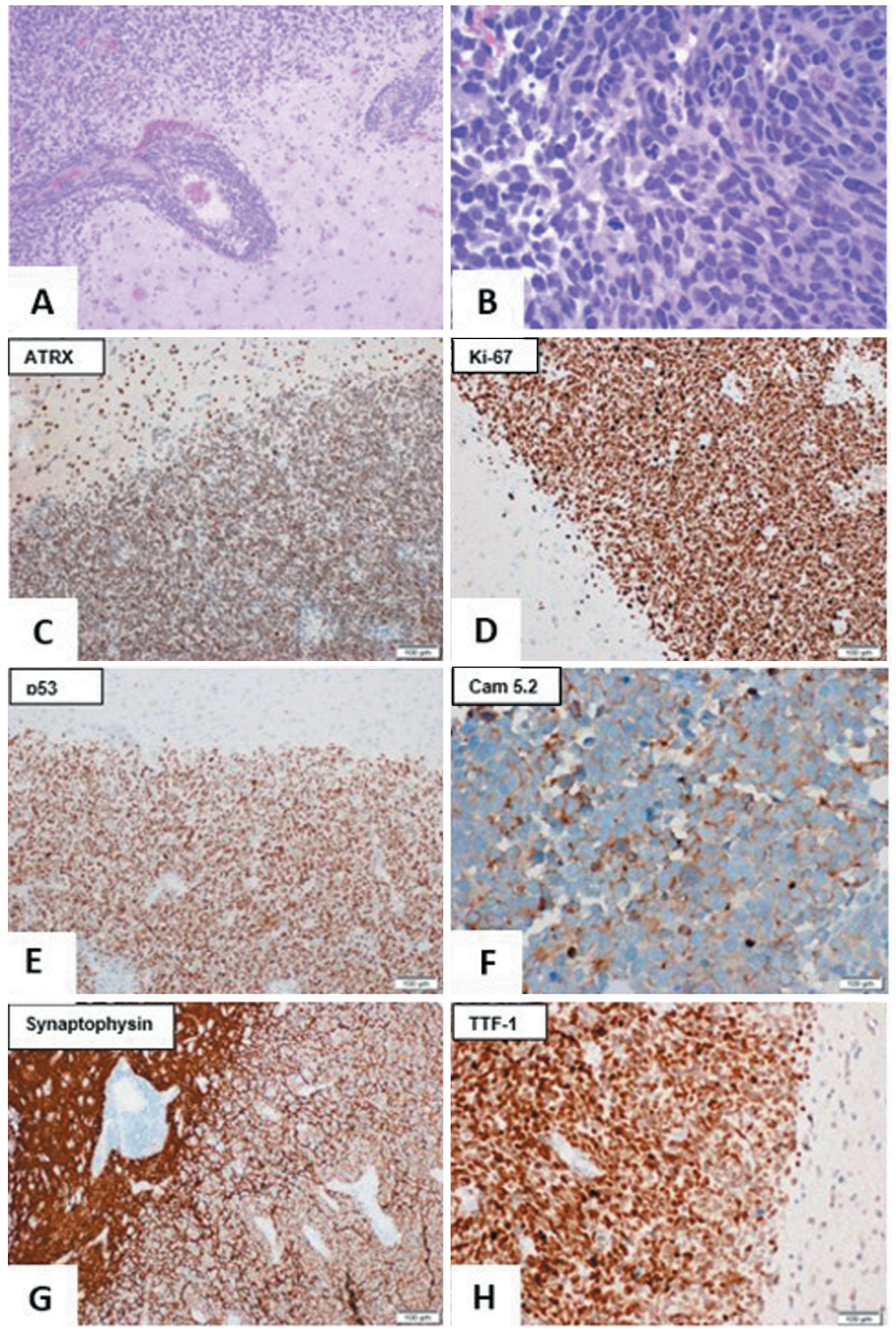

Figure 3. Hematoxylin and eosin $(H \& E)$ and immunohistochemical (IHC) stains for Patient 2. The tumor is highly cellular with an abrupt margin with focal geographic micronecrosis. The tumor cells have scant eosinophilic cytoplasm with irregular hyperchromatic nuclei lacking nucleoli. ATRX expression is retained, and a manual semiquantitative assessment of Ki-67 labelling shows a proliferative index of $60 \%$. Nuclear p53 overexpression is noted in about 50\% of tumor cell nuclei. CAM5.2 shows delicate positive expression, synaptophysin highlights normal brain, and at the tumor-brain interface there is delicate granular positivity extends between clusters of tumor cells, and TTF1 shows strong uniform nuclear expression. 


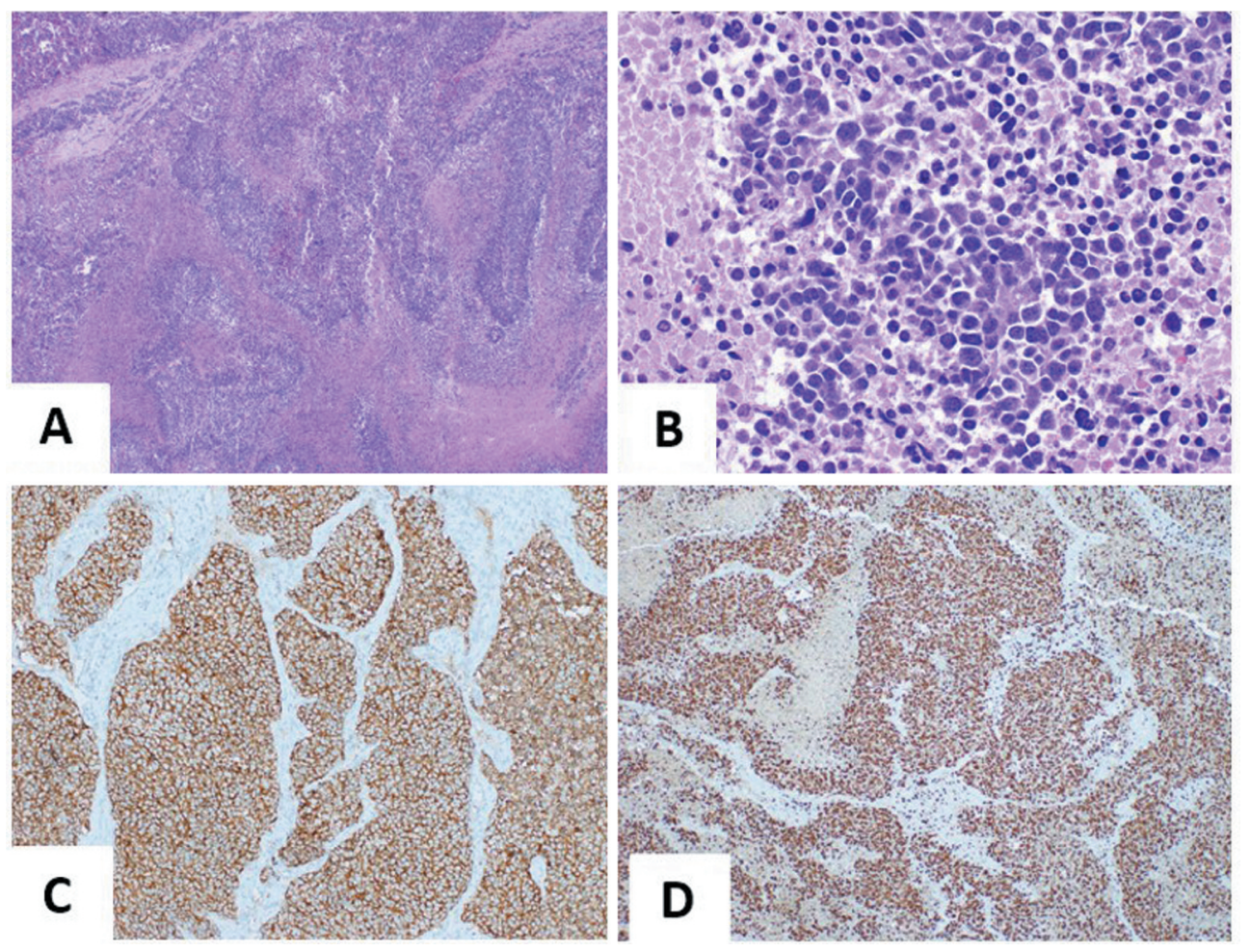

Figure 4. Hematoxylin and eosin $(H \& E)$ and immunohistochemical (IHC) stains for Patient 3. High-grade malignancy composed of blue round cells. (A) Low power view illustrating extensive tumor necrosis. (B) High power view illustrating high-grade morphologic features with a high N/C ratio. (C) The tumor cells were strongly and diffusely positive for synaptophysin. (D) The Ki67 stain demonstrated a proliferation index of $80 \%$.

subtype classification helped to resolve a diagnosis of small/large cell neuroendocrine carcinoma of the lung for this metastatic patient.

\section{Patient 3}

Clinical presentation, imaging, and surgical intervention. A 59-year-old female suffered a pathologic fracture of her right humerus, and upon initial assessment was subsequently determined to have an associated soft tissue mass. She underwent resection of the mass with reconstruction of her right humerus using an intercalary prosthetic graft. Her staging CT in the thorax/abdomen revealed right axillary, left supraclavicular, and mediastinal lymphadenopathy with an epicardial mass, which were concerning for metastatic disease.

Pathology evaluation. Histological evaluation of the fracture site of her right humerus revealed a high-grade malignancy composed of blue round cells, with frequent mitotic activity and extensive necrosis (Figure 4A and B). Immunohistochemical studies demonstrated that the tumor cells were strongly and diffusely positive for synaptophysin (Figure 4C), focally positive for chromogranin, and negative for keratin AE1/AE3/CAM 5.2, CEA (polyclonal), KER903, CK7, CK20, CD99, TTF-1, Desmin, actin, CD45, S-100 and bcl-2. Ki-67 was positive in $80 \%$ of the tumor cell nuclei (3+) by manual quantitative analysis (Figure 4D). Cytogenetics demonstrated a normal female karyotype and the possibility of a hematopoietic malignancy was ruled out. Molecular testing by RT-DNA amplification did not detect a fusion transcript for EWSR1/FLI, and there was no detection of any rearrangements involving the EWSR1 (22q12) locus.

Molecular tumor classification by CancerTYPE ID ${ }^{\circledR}$. A CancerTYPE ID ${ }^{\circledR}$ test was ordered, which determined that there was a $96 \%$ probability that the main cancer type was neuroendocrine in nature. Of the potential subtypes that were determined, the CancerTYPE ID ${ }^{\circledR}$ test had assigned a $63 \%$ probability that the tumor was a small/large cell lung carcinoma, and 33\% probability that the tumor was a Merkel cell carcinoma.

Impact of molecular tumor classification and treatment. These subtypes correspond to the high-grade description of the tumor's morphology. After treatment, restaging 

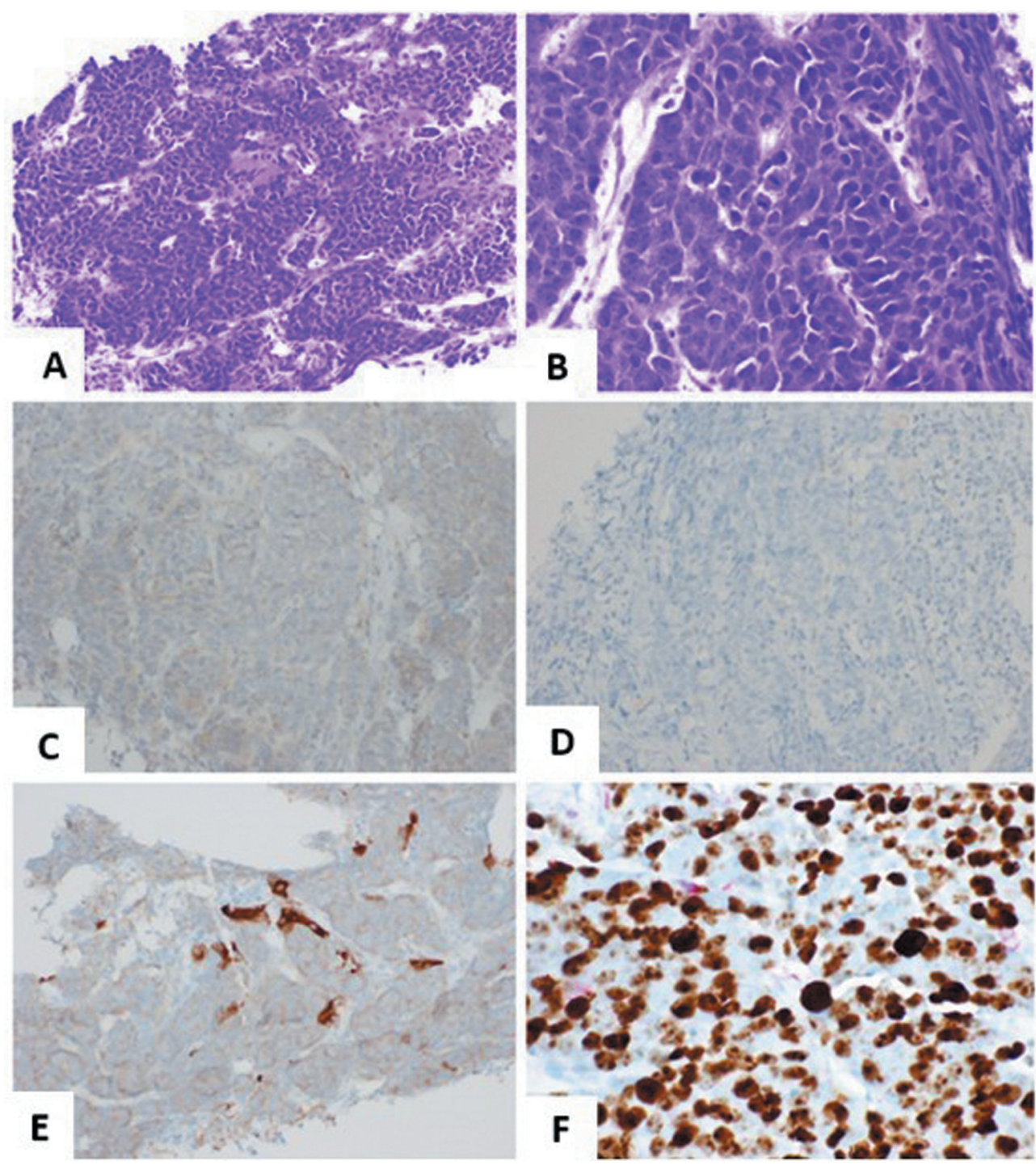

Figure 5. Patient 4. A CT-guided biopsy of a liver mass was morphologically described on hematoxylin and eosin (H\&E) as a poorly differentiated malignant neoplasm. (A) The malignant cells were cohesive, growing in sheets with enlarged vesicular nuclei and variable amounts of cytoplasm. (B) Abundant mitotic activity and apoptosis were observed. The malignant cells were immunohistochemically negative for $(C)$ Synaptophysin and $(D)$ Chromogranin; while demonstrating (E) faint positivity for OSCAR; as well as demonstrating (F) a Ki-67 proliferation rate of greater than $80 \%$.

radiographs of her right humerus demonstrated improvement consistent with a response to her therapy.

\section{Patient 4}

Clinical presentation, imaging, and surgical intervention. A 57-year-old woman with history of vertigo and migraines presented to the Emergency Department of an outside hospital with diplopia, an intractable headache and nausea. An MRI of the brain demonstrated metastatic disease to the left skull with extension into the left cavernous sinus and encasement of left cavernous carotid artery.
The tumor extended to the left posterior orbit and superior orbital fissure with involvement of the distribution of maxillary division of left trigeminal nerve. There was impingement observed upon compression of left optic nerve by tumor at the level of the optic foramen. A CT of the abdomen and pelvis identified hepatomegaly with numerous solid masses throughout the liver.

A CT of the thorax identified multiple lung masses associated with extensive mediastinal adenopathy. An MRI of the abdomen identified small bilateral pleural effusions, multiple hepatic lesions with unusual enhancement, at least 6 lesions in left hepatic lobe and multi-segmental multifocal 
lesions in the right lobe with a large confluence of lesions in central right liver. A PET scan demonstrated near complete collapse of the left lung with large space-occupying pleural effusion and hypermetabolic left perihilar soft tissue mass, multiple hypermetabolic liver metastases, with increased uptake in the distal esophagus and gastric cardia, a hypermetabolic focus in the region of the left cavernous sinus, hypermetabolic thoracic, right supraclavicular, infraclavicular and peripancreatic lymph nodes. A liver biopsy was obtained for diagnosis and treatment planning.

Pathology evaluation. A CT-guided biopsy of a liver mass was morphologically described on $\mathrm{H} \& \mathrm{E}$ as a poorly differentiated malignant neoplasm (Figure 5A and B). The malignant cells were initially characterized as negative for expression of AE1/AE3, CK7, CK20, PAX8, TTF1, GATA3, CD45, Hepatocyte Specific Antigen (Hep Par-1), S100, CD56, Synaptophysin and Chromogranin. Per a review at John's Hopkins Hospital, further immunostains characterized the malignant cells as focally positive for CAM 5.2 and AE1/AE3; as well as negative for expression of CK903, INSM1, CD99, CD34, ERG, Arginase, Glypican-3 and p40 with retained expression of INI-1.

Since the specimen was morphologically consistent with a large cell neuroendocrine carcinoma, neuroendocrine markers were repeated (CD56, Synaptophysin and Chromogranin) and were negative (Figure 5C and D), which corroborated the initial Synaptophysin and Chromogranin negativity. Squamous markers (CK5/6, p63 and p40) were also negative. OSCAR was faintly positive and a Ki-67/CD45 (multiplex) immunohistochemical study demonstrated a proliferation rate of greater than $80 \%$ upon review at Moffitt Cancer Center (Figure 5E and F). The immunoprofile in this tumor was negative for repeated attempts at immunostains for neuroendocrine markers, which presented a diagnostic challenge, as large-cell neuroendocrine carcinoma (LCNEC) typically demonstrates positivity in at least one neuroendocrine marker.

Molecular tumor classification by CancerTYPE ID ${ }^{\circledR}$. For further clarification, Biotheranostics CancerTYPE $I D^{\circledR}$ was requested, which reported a $90 \%$ probability of small/large cell lung neuroendocrine carcinoma. Other cancer types with less than a 5\% probability included cervical adenocarcinoma, lung adenocarcinoma, squamous cell carcinoma of the lung, head and neck, skin or cervix; as well as thyroid follicular/papillary or medullary carcinoma. Lack of PAX8 expression excluded cervical and thyroid primaries and lack of TTF1 expression excluded a lung primary as a consideration.

Impact of molecular tumor classification and treatment. The results of the Biotheranostics CancerTYPE $I D^{\circledR}$ were invaluable in context of this uncommonly observed immunoprofile, as the tumor's histomorphology, mitotic rate as well as the proliferative index were consistent with a
LCNEC of pulmonary origin. These findings assisted in determining clinical management, as these results enabled treatment-based decisions to be made that could provide systemic treatment with greater precision when compared to making treatment-based decisions agnostic of the CancerTYPE ID ${ }^{\circledR}$ test results. The patient was subsequently treated with palliative chemotherapy (carboplatin and etoposide). Interim restaging scans revealed interval improvement in mediastinal lymphadenopathy, as well as a decrease in size of numerous liver metastases and there was no progression in other sites. Clinically, her ECOG improved dramatically with total independence in ADL, while she experienced a resolution of her nausea and she reported improvement in left eye vision. The patient has continued on palliative systemic chemotherapy with disease stability and increased quality of life.

\section{Discussion}

Here we report four appropriate clinical scenarios that highlight the utility of a GEP-molecular based assay to identify NEN subtypes and tumor sites of origin when dealing with metastatic NENs.

These cases demonstrated that the CancerTYPE ID ${ }^{\circledR}$ test facilitated in the resolution of particularly challenging diagnoses for primary and metastatic NENs. In a blinded study evaluating the performance of CancerTYPE ID ${ }^{\circledR}$ that included 44 metastatic and 31 primary NENs, the assay demonstrated a high level of accuracy for the classification of both well-differentiated (97\%) and poorly differentiated NENs (87\%). The CancerTYPE ID ${ }^{\circledR}$ test was determined to be significantly more accurate than the use of histology and IHCs to establish the neoplasms' primary sites $(43,62)$. Further analysis demonstrated that 15 of 87 cancer-related genes demonstrated sufficient discriminatory value for accurate subtyping of NENs. Given the significance of determining the anatomic site of origin for clinical management, the ability of CancerTYPE ID ${ }^{\circledR}$ to differentiate NEN subtypes supports the clinical utility of molecular tumor classification (93). Differentiating the NEN's subtype and anatomic site of origin for an indeterminate NEN has significant implications for clinical management.

The importance of determining the tumor site of origin is further emphasized when considering that therapeutic indications granted by the Food and Drug Administration (FDA) are largely cancer type specific, with the recent approval for immunotherapy for microsatellite instabilityhigh (MSI-H) or mismatch repair deficient (dMMR) status in solid tumors being a notable unprecedented exception (100). For metastatic tumors the accurate diagnosis of their site of origin is important not only for treatment decisions but also in determining cancer risk for the patients' relatives (101). Development of targeted therapies and precision- 
based management has become increasingly relevant given the driver mutations that have been identified in NENs. Recent efforts have included investigation of inhibitors targeting signaling in the $\mathrm{Wnt} / \beta$-catenin pathway, the $\mathrm{PI} 3 \mathrm{~K} / \mathrm{AKT} / \mathrm{mTOR}$ pathway (everolimus), the MET pathway and the vascular endothelial factor (VEGF) pathway (sunitinib) (11, 15, 17, 31-33, 37, 38, 59, 102-114). These investigative efforts were typically focused on specific organ systems as dictated by the requirement for the approval of targeted agents. Thus, the clinical need for determination of the tumor anatomic site of origin is a plausible reason to utilize a GEP-based assay as an effective tool for the clinical management of NENs $(11,17,31-33,35,37-41,63,92$, 103109, 115, 116).

\section{Conflicts of Interest}

The Authors have no conflicts of interest to declare.

\section{Authors' Contributions}

James Saller and Sameer Al Diffalha drafted the manuscript, Mintallah Haider revised the original draft, James Saller completed the references, Domenico Coppola planned, originated and supervised the study.

\section{Acknowledgements}

The project described was supported by H. Lee Moffitt Cancer Center, Department of Pathology departmental funds. Editorial assistance was provided by the Moffitt Cancer Center's Office of Scientific Publishing by Daley Drucker. No compensation was given beyond her regular salary.

\section{References}

1 Meiri E, Mueller WC, Rosenwald S, Zepeniuk M, Klinke E, Edmonston TB, Werner M, Lass U, Barshack I, Feinmesser M, Huszar M, Fogt F, Ashkenazi K, Sanden M, Goren E, Dromi N, Zion O, Burnstein I, Chajut A, Spector Y and Aharonov R: A second-generation microRNA-based assay for diagnosing tumor tissue origin. Oncologist 17(6): 801-812, 2012. PMID: 22618571. DOI: 10.1634/theoncologist.2011-0466

2 Lin $\mathrm{F}$ and Liu $\mathrm{H}$ : Immunohistochemistry in undifferentiated neoplasm/tumor of uncertain origin. Arch Pathol Lab Med 138(12): 1583-1610, 2014. PMID: 25427040. DOI: 10.5858/arpa.2014-0061-RA

3 Bugat R, Bataillard A, Lesimple T, Voigt JJ, Culine S, Lortholary A, Merrouche Y, Ganem G, Kaminsky MC, Negrier S, Perol M, Laforêt C, Bedossa P, Bertrand G, Coindre JM, Fizazi K and FNCLCC: Summary of the Standards, Options and Recommendations for the management of patients with carcinoma of unknown primary site (2002). Br J Cancer 89(Suppl 1): S59S66, 2003. PMID: 12915904. DOI: 10.1038/sj.bjc.6601085

4 Weiss LM, Chu P, Schroeder BE, Singh V, Zhang Y, Erlander MG and Schnabel CA: Blinded comparator study of immunohistochemical analysis versus a 92-gene cancer classifier in the diagnosis of the primary site in metastatic tumors. J Mol Diagn 15(2): 263-269, 2013. PMID: 23287002. DOI: $10.1016 /$ j.jmoldx.2012.10.001

5 Rosenwald S, Gilad S, Benjamin S, Lebanony D, Dromi N, Faerman A, Benjamin H, Tamir R, Ezagouri M, Goren E, Barshack I, Nass D, Tobar A, Feinmesser M, Rosenfeld N, Leizerman I, Ashkenazi K, Spector Y, Chajut A and Aharonov R: Validation of a microRNA-based qRT-PCR test for accurate identification of tumor tissue origin. Mod Pathol 23(6): 814-823, 2010. PMID: 20348879. DOI: $10.1038 /$ modpathol.2010.57

6 Kerr SE, Schnabel CA, Sullivan PS, Zhang Y, Singh V, Carey B, Erlander MG, Highsmith WE, Dry SM and Brachtel EF: Multisite validation study to determine performance characteristics of a 92gene molecular cancer classifier. Clin Cancer Res 18(14): 39523960, 2012. PMID: 22648269. DOI: 10.1158/1078-0432.CCR-120920

7 Zuetenhorst JM and Taal BG: Metastatic carcinoid tumors: a clinical review. Oncologist 10(2): 123-131, 2005. PMID: 15709214. DOI: 10.1634/theoncologist.10-2-123

8 Weinstock B, Ward SC, Harpaz N, Warner RR, Itzkowitz S and Kim MK: Clinical and prognostic features of rectal neuroendocrine tumors. Neuroendocrinology 98(3): 180-187, 2013. PMID: 24080744. DOI: $10.1159 / 000355612$

9 Shen C, Yin Y, Chen H, Tang S, Yin X, Zhou Z, Zhang B and Chen Z: Neuroendocrine tumors of colon and rectum: validation of clinical and prognostic values of the World Health Organization 2010 grading classifications and European Neuroendocrine Tumor Society staging systems. Oncotarget 8(13): 22123-22134, 2017. PMID: 27902460. DOI: 10.18632/oncotarget.13641

10 Rickman DS, Beltran H, Demichelis F and Rubin MA: Biology and evolution of poorly differentiated neuroendocrine tumors. Nat Med 23(6): 1-10, 2017. PMID: 28586335. DOI: 10.1038/nm.4341

11 Hobday TJ, Qin R, Reidy-Lagunes D, Moore MJ, Strosberg J, Kaubisch A, Shah M, Kindler HL, Lenz HJ, Chen H and Erlichman C: Multicenter phase II trial of temsirolimus and bevacizumab in pancreatic neuroendocrine tumors. J Clin Oncol 33(14): 1551-1556, 2015. PMID: 25488966. DOI: 10.1200/ JCO.2014.56.2082

12 Shi C and Klimstra DS: Pancreatic neuroendocrine tumors: pathologic and molecular characteristics. Semin Diagn Pathol 31(6): 498-511, 2014. PMID: 25441311. DOI: 10.1053/j.semdp. 2014.08.008

13 Banck MS, Kanwar R, Kulkarni AA, Boora GK, Metge F, Kipp BR, Zhang L, Thorland EC, Minn KT, Tentu R, Eckloff BW, Wieben ED, Wu Y, Cunningham JM, Nagorney DM, Gilbert JA, Ames MM and Beutler AS: The genomic landscape of small intestine neuroendocrine tumors. J Clin Invest 123(6): 2502-2508, 2013. PMID: 23676460. DOI: 10.1172/JCI67963

14 Yachida S, Vakiani E, White CM, Zhong Y, Saunders T, Morgan R, de Wilde RF, Maitra A, Hicks J, Demarzo AM, Shi C, Sharma R, Laheru D, Edil BH, Wolfgang CL, Schulick RD, Hruban RH, Tang LH, Klimstra DS and Iacobuzio-Donahue CA: Small cell and large cell neuroendocrine carcinomas of the pancreas are genetically similar and distinct from welldifferentiated pancreatic neuroendocrine tumors. Am J Surg Pathol 36(2): 173-184, 2012. PMID: 22251937. DOI: 10.1097/PAS.0b013e3182417d36

15 Sun J: Pancreatic neuroendocrine tumors. Intractable Rare Dis Res 6(1): 21-28, 2017. PMID: 28357177. DOI: 10.5582/irdr.2017. 01007 
16 Sorbye H, Strosberg J, Baudin E, Klimstra DS and Yao JC: Gastroenteropancreatic high-grade neuroendocrine carcinoma. Cancer 120(18): 2814-2823, 2014. PMID: 24771552. DOI: $10.1002 /$ cncr.28721

17 Ohmoto A, Rokutan H and Yachida S: Pancreatic neuroendocrine neoplasms: basic biology, current treatment strategies and prospects for the future. Int J Mol Sci 18(1): 143, 2017. PMID: 28098761. DOI: 10.3390/ijms18010143

18 Scarpa A, Chang DK, Nones K, Corbo V, Patch AM, Bailey P, Lawlor RT, Johns AL, Miller DK, Mafficini A, Rusev B, Scardoni M, Antonello D, Barbi S, Sikora KO, Cingarlini S, Vicentini C, McKay S, Quinn MC, Bruxner TJ, Christ AN, Harliwong I, Idrisoglu S, McLean S, Nourse C, Nourbakhsh E, Wilson PJ, Anderson MJ, Fink JL, Newell F, Waddell N, Holmes O, Kazakoff SH, Leonard C, Wood S, Xu Q, Nagaraj SH, Amato E, Dalai I, Bersani S, Cataldo I, Dei Tos AP, Capelli P, Davì MV, Landoni L, Malpaga A, Miotto M, Whitehall VL, Leggett BA, Harris JL, Harris J, Jones MD, Humphris J, Chantrill LA, Chin V, Nagrial AM, Pajic M, Scarlett CJ, Pinho A, Rooman I, Toon C, Wu J, Pinese M, Cowley M, Barbour A, Mawson A, Humphrey ES, Colvin EK, Chou A, Lovell JA, Jamieson NB, Duthie F, Gingras MC, Fisher WE, Dagg RA, Lau LM, Lee M, Pickett HA, Reddel RR, Samra JS, Kench JG, Merrett ND, Epari K, Nguyen NQ, Zeps N, Falconi M, Simbolo M, Butturini G, Van Buren G, Partelli S, Fassan M, Australian Pancreatic Cancer Genome Initiative, Khanna KK, Gill AJ, Wheeler DA, Gibbs RA, Musgrove EA, Bassi C, Tortora G, Pederzoli P, Pearson JV, Waddell N, Biankin AV and Grimmond SM: Whole-genome landscape of pancreatic neuroendocrine tumours. Nature 543(7643): 65-71, 2017. PMID: 28199314. DOI: 10.1038/nature21063

19 Ikezono Y, Koga H, Akiba J, Abe M, Yoshida T, Wada F, Nakamura T, Iwamoto H, Masuda A, Sakaue T, Yano H, Tsuruta $\mathrm{O}$ and Torimura T: Pancreatic neuroendocrine tumors and EMT behavior are driven by the CSC marker DCLK1. Mol Cancer Res 15(6): 744-752, 2017. PMID: 28179411. DOI: 10.1158/15417786.MCR-16-0285

20 Akkari L, Gocheva V, Kester JC, Hunter KE, Quick ML, Sevenich L, Wang HW, Peters C, Tang LH, Klimstra DS, Reinheckel T and Joyce JA: Distinct functions of macrophagederived and cancer cell-derived cathepsin $\mathrm{Z}$ combine to promote tumor malignancy via interactions with the extracellular matrix. Genes Dev 28(19): 2134-2150, 2014. PMID: 25274726. DOI: $10.1101 / \operatorname{gad} .249599 .114$

21 Reinheckel T, Peters C, Krüger A, Turk B and Vasiljeva O: Differential impact of cysteine cathepsins on genetic mouse models of de novo carcinogenesis: Cathepsin B as emerging therapeutic target. Front Pharmacol 3: 133, 2012. PMID: 22798952. DOI: 10.3389/fphar.2012.00133

22 Hirano M, Hashimoto S, Yonemura S, Sabe H and Aizawa S: EPB41L5 functions to post-transcriptionally regulate cadherin and integrin during epithelial-mesenchymal transition. J Cell Biol 182(6): 1217-1230, 2008. PMID: 18794329. DOI: 10.1083/ jcb.200712086

23 Ilett EE, Langer SW, Olsen IH, Federspiel B, Kjær A and Knigge $\mathrm{U}$ : Neuroendocrine carcinomas of the gastroenteropancreatic system: a comprehensive review. Diagnostics (Basel) 5(2): 119176, 2015. PMID: 26854147. DOI: 10.3390/diagnostics5020119

24 Galván JA, Astudillo A, Vallina A, Fonseca PJ, Gómez-Izquierdo L, García-Carbonero $\mathrm{R}$ and González MV: Epithelialmesenchymal transition markers in the differential diagnosis of gastroenteropancreatic neuroendocrine tumors. Am J Clin Pathol 140(1): 61-72, 2013. PMID: 23765535. DOI: 10.1309/AJCPIV 40ISTBXRAX

25 Briest $\mathrm{F}$ and Grabowski P: PI3K-AKT-mTOR-signaling and beyond: the complex network in gastroenteropancreatic neuroendocrine neoplasms. Theranostics 4(4): 336-365, 2014. PMID: 24578720. DOI: 10.7150/thno.7851

26 Modlin IM, Oberg K, Chung DC, Jensen RT, de Herder WW, Thakker RV, Caplin M, Delle Fave G, Kaltsas GA, Krenning EP, Moss SF, Nilsson O, Rindi G, Salazar R, Ruszniewski P and Sundin A: Gastroenteropancreatic neuroendocrine tumours. Lancet Oncol 9(1): 61-72, 2008. PMID: 18177818. DOI: 10.1016/S1470-2045(07)70410-2

27 Board PDQATE: Pancreatic neuroendocrine tumors (islet cell tumors) treatment $(\mathrm{pdq}(\mathrm{r}))$ : Health professional version. In: Pdq cancer information summaries. Bethesda, MD, USA, National Cancer Institute USA, 2002.

28 Kim ST, Lee SJ, Park SH, Park JO, Lim HY, Kang WK, Lee J and Park YS: Genomic profiling of metastatic gastroenteropancreatic neuroendocrine tumor (GEP-NET) patients in the personalizedmedicine era. J Cancer 7(9): 1044-1048, 2016. PMID: 27326246. DOI: $10.7150 /$ jca. 14815

29 Pal S, Milowsky M, Elvin J, Ali S, Hoffman-censits J, Vergilio J, Suh J, Mian B, Fisher H, Nazeer T, Miller V, Stephens P and Ross $\mathrm{J}$ : Comprehensive genomic profiling of neuroendocrine carcinoma of the prostate. Journal of Clinical Oncology 34(2_suppl): 187187, 2020. DOI: 10.1200/jco.2016.34.2_suppl.187

30 Pelosi G, Papotti M, Rindi G and Scarpa A: Unraveling tumor grading and genomic landscape in lung neuroendocrine tumors. Endocr Pathol 25(2): 151-164, 2014. PMID: 24771462. DOI: $10.1007 / \mathrm{s} 12022-014-9320-0$

31 Raymond E, Hobday T, Castellano D, Reidy-Lagunes D, GarcíaCarbonero R and Carrato A: Therapy innovations: tyrosine kinase inhibitors for the treatment of pancreatic neuroendocrine tumors. Cancer Metastasis Rev 30 Suppl 1: 19-26, 2011. PMID: 21308478. DOI: $10.1007 / \mathrm{s} 10555-011-9291-2$

32 Yao JC, Pavel M, Lombard-Bohas C, Van Cutsem E, Voi M, Brandt U, He W, Chen D, Capdevila J, de Vries EGE, Tomassetti P, Hobday T, Pommier R and Öberg K: Everolimus for the treatment of advanced pancreatic neuroendocrine tumors: overall survival and circulating biomarkers from the randomized, phase III RADIANT-3 study. J Clin Oncol 34(32): 3906-3913, 2016. PMID: 27621394. DOI: 10.1200/JCO.2016.68.0702

33 Geis C, Fendrich V, Rexin P, Di Fazio P, Bartsch DK, Ocker M, Quint $\mathrm{K}$ and Heverhagen AE: Ileal neuroendocrine tumors show elevated activation of mammalian target of rapamycin complex. J Surg Res 194(2): 388-393, 2015. PMID: 25439321. DOI: 10.1016/j.jss.2014.10.052

34 Dardenne E, Beltran H, Benelli M, Gayvert K, Berger A, Puca L, Cyrta J, Sboner A, Noorzad Z, MacDonald T, Cheung C, Yuen KS, Gao D, Chen Y, Eilers M, Mosquera JM, Robinson BD, Elemento O, Rubin MA, Demichelis F and Rickman DS: N-Myc induces an EZH2-mediated transcriptional program driving neuroendocrine prostate cancer. Cancer Cell 30(4): 563-577, 2016. PMID: 27728805. DOI: 10.1016/j.ccell.2016.09.005

35 Fenner A: Prostate cancer: BRN2 is a neuroendocrine driver. Nat Rev Urol 14(1): 10, 2017. PMID: 27843142. DOI: 10.1038/ nrurol.2016.237

36 Bishop JL, Thaper D, Vahid S, Davies A, Ketola K, Kuruma H, Jama R, Nip KM, Angeles A, Johnson F, Wyatt AW, Fazli L, 
Gleave ME, Lin D, Rubin MA, Collins CC, Wang Y, Beltran H and Zoubeidi A: The master neural transcription factor BRN2 is an androgen receptor-suppressed driver of neuroendocrine differentiation in prostate cancer. Cancer Discov 7(1): 54-71, 2017. PMID: 27784708. DOI: $10.1158 / 2159-8290 . C D-15-1263$

37 Maxwell JE, Sherman SK and Howe JR: Translational diagnostics and therapeutics in pancreatic neuroendocrine tumors. Clin Cancer Res 22(20): 5022-5029, 2016. PMID: 27742788. DOI: 10.1158/1078-0432.CCR-16-0435

38 Lyons YA, Frumovitz M and Soliman PT: Response to MEK inhibitor in small cell neuroendocrine carcinoma of the cervix with a KRAS mutation. Gynecol Oncol Rep 10: 28-29, 2014. PMID: 26075998. DOI: 10.1016/j.gore.2014.09.003

39 Beltran H, Rickman DS, Park K, Chae SS, Sboner A, MacDonald TY, Wang Y, Sheikh KL, Terry S, Tagawa ST, Dhir R, Nelson JB, de la Taille A, Allory Y, Gerstein MB, Perner S, Pienta KJ, Chinnaiyan AM, Wang Y, Collins CC, Gleave ME, Demichelis F, Nanus DM and Rubin MA: Molecular characterization of neuroendocrine prostate cancer and identification of new drug targets. Cancer Discov 1(6): 487495, 2011. PMID: 22389870. DOI: 10.1158/2159-8290.CD-110130

40 Kidd M and Modlin IM: Therapy: The role of liquid biopsies to manage and predict PRRT for NETs. Nat Rev Gastroenterol Hepatol 14(6): 331-332, 2017. PMID: 28293026. DOI: 10.1038/nrgastro.2017.26

41 Park C, Ha SY, Kim ST, Kim HC, Heo JS, Park YS, Lauwers G, Lee $\mathrm{J}$ and Kim KM: Identification of the BRAF V600E mutation in gastroenteropancreatic neuroendocrine tumors. Oncotarget 7(4): 4024-4035, 2016. PMID: 26684240. DOI: 10.18632/oncotarget. 6602

42 Akintola-Ogunremi O, Pfeifer JD, Tan BR, Yan Y, Zhu X, Hart J, Goldblum JR, Burgart L, Lauwers GY, Montgomery E, Lewin D, Washington K, Bronner M, Xiao SY, Greenson JK, Lamps L, Lazenby A and Wang HL: Analysis of protein expression and gene mutation of c-kit in colorectal neuroendocrine carcinomas. Am J Surg Pathol 27(12): 1551-1558, 2003. PMID: 14657715 DOI: $10.1097 / 00000478-200312000-00008$

43 Srivastava A and Hornick JL: Immunohistochemical staining for CDX-2, PDX-1, NESP-55, and TTF-1 can help distinguish gastrointestinal carcinoid tumors from pancreatic endocrine and pulmonary carcinoid tumors. Am J Surg Pathol 33(4): 626-632, 2009. PMID: 19065104. DOI: 10.1097/PAS.0b013e31818d7d8b

44 Freis P, Graillot E, Rousset P, Hervieu V, Chardon L, LombardBohas $\mathrm{C}$ and Walter T: Prognostic factors in neuroendocrine carcinoma: biological markers are more useful than histomorphological markers. Sci Rep 7: 40609, 2017. PMID: 28074897. DOI: $10.1038 /$ srep40609

45 Kim JY and Hong SM: Recent updates on neuroendocrine tumors from the gastrointestinal and pancreatobiliary tracts. Arch Pathol Lab Med 140(5): 437-448, 2016. PMID: 27128301. DOI: 10.5858/arpa.2015-0314-RA

46 Castro-Vega LJ, Letouzé E, Burnichon N, Buffet A, Disderot $\mathrm{PH}$, Khalifa E, Loriot C, Elarouci N, Morin A, Menara M, Lepoutre-Lussey C, Badoual C, Sibony M, Dousset B, Libé R, Zinzindohoue F, Plouin PF, Bertherat J, Amar L, de Reyniès A, Favier $\mathrm{J}$ and Gimenez-Roqueplo AP: Multi-omics analysis defines core genomic alterations in pheochromocytomas and paragangliomas. Nat Commun 6: 6044, 2015. PMID: 25625332. DOI: $10.1038 /$ ncomms 7044
47 Fishbein L, Leshchiner I, Walter V, Danilova L, Robertson AG, Johnson AR, Lichtenberg TM, Murray BA, Ghayee HK, Else T, Ling S, Jefferys SR, de Cubas AA, Wenz B, Korpershoek E, Amelio AL, Makowski L, Rathmell WK, Gimenez-Roqueplo AP, Giordano TJ, Asa SL, Tischler AS, Cancer Genome Atlas Research Network, Pacak K, Nathanson KL and Wilkerson MD: Comprehensive molecular characterization of pheochromocytoma and paraganglioma. Cancer Cell 31(2): 181-193, 2017. PMID: 28162975. DOI: 10.1016/j.ccell.2017.01.001

48 Fishbein L, Khare S, Wubbenhorst B, DeSloover D, D'Andrea K, Merrill S, Cho NW, Greenberg RA, Else T, Montone K, LiVolsi V, Fraker D, Daber R, Cohen DL and Nathanson KL: Wholeexome sequencing identifies somatic ATRX mutations in pheochromocytomas and paragangliomas. Nat Commun 6: 6140, 2015. PMID: 25608029. DOI: $10.1038 /$ ncomms 7140

49 Sahnane N, Furlan D, Monti M, Romualdi C, Vanoli A, Vicari E, Solcia E, Capella C, Sessa F and La Rosa S: Microsatellite unstable gastrointestinal neuroendocrine carcinomas: a new clinicopathologic entity. Endocr Relat Cancer 22(1): 35-45, 2015. PMID: 25465415. DOI: 10.1530/ERC-14-0410

50 Genomics of phaeochromocytomas and paragangliomas. Nat Rev Endocrinol 11(4): 194-194, 2015. DOI: 10.1038/nrendo.2015.22

51 Favier J, Amar L and Gimenez-Roqueplo AP: Paraganglioma and phaeochromocytoma: from genetics to personalized medicine. Nat Rev Endocrinol 11(2): 101-111, 2015. PMID: 25385035. DOI: 10.1038/nrendo.2014.188

52 Mosquera JM, Beltran H, Park K, MacDonald TY, Robinson BD, Tagawa ST, Perner S, Bismar TA, Erbersdobler A, Dhir R, Nelson JB, Nanus DM and Rubin MA: Concurrent AURKA and MYCN gene amplifications are harbingers of lethal treatment-related neuroendocrine prostate cancer. Neoplasia 15(1): 1-10, 2013. PMID: 23358695. DOI: 10.1593/neo.121550

53 Clegg N, Ferguson C, True LD, Arnold H, Moorman A, Quinn JE, Vessella RL and Nelson PS: Molecular characterization of prostatic small-cell neuroendocrine carcinoma. Prostate 55(1): 55-64, 2003. PMID: 12640661. DOI: 10.1002/pros.10217

54 Hammond WA, Crozier JA, Nakhleh RE and Mody K: Genomic profiling of high-grade large-cell neuroendocrine carcinoma of the colon. J Gastrointest Oncol 7(2): E22-E24, 2016. PMID: 27034803. DOI: 10.3978/j.issn.2078-6891.2015.090

55 Miyoshi T, Umemura S, Matsumura Y, Mimaki S, Tada S, Makinoshima H, Ishii G, Udagawa H, Matsumoto S, Yoh K, Niho S, Ohmatsu H, Aokage K, Hishida T, Yoshida J, Nagai K, Goto $\mathrm{K}$, Tsuboi $\mathrm{M}$ and Tsuchihara K: Genomic profiling of large-cell neuroendocrine carcinoma of the lung. Clin Cancer Res 23(3): 757-765, 2017. PMID: 27507618. DOI: 10.1158/1078-0432.CCR16-0355

56 Backman S, Norlén O, Eriksson B, Skogseid B, Stålberg P and Crona J: Detection of somatic mutations in gastroenteropancreatic neuroendocrine tumors using targeted deep sequencing. Anticancer Res 37(2): 705-712, 2017. PMID: 28179320. DOI: 10.21873/anticanres. 11367

57 Meeker A and Heaphy C: Gastroenteropancreatic endocrine tumors. Mol Cell Endocrinol 386(1-2): 101-120, 2014. PMID: 23906538. DOI: 10.1016/j.mce.2013.07.015

58 Mapelli P, Aboagye EO, Stebbing J and Sharma R: Epigenetic changes in gastroenteropancreatic neuroendocrine tumours. Oncogene 34(34): 4439-4447, 2015. PMID: 25435371. DOI: 10.1038/onc. 2014.379 
59 Uri I and Grozinsky-Glasberg S: Current treatment strategies for patients with advanced gastroenteropancreatic neuroendocrine tumors (GEP-NETs). Clin Diabetes Endocrinol 4: 16, 2018. PMID: 30009041. DOI: 10.1186/s40842-018-0066-3

60 Lee HS, Chen M, Kim JH, Kim WH, Ahn S, Maeng K, Allegra CJ, Kaye FJ, Hochwald SN and Zajac-Kaye M: Analysis of 320 gastroenteropancreatic neuroendocrine tumors identifies TS expression as independent biomarker for survival. Int J Cancer 135(1): 128-137, 2014. PMID: 24347111. DOI: 10.1002/ijc.28675

61 Pinato DJ, Tan TM, Toussi ST, Ramachandran R, Martin N, Meeran K, Ngo N, Dina R and Sharma R: An expression signature of the angiogenic response in gastrointestinal neuroendocrine tumours: correlation with tumour phenotype and survival outcomes. Br J Cancer 110(1): 115-122, 2014. PMID: 24231952. DOI: $10.1038 /$ bjc.2013.682

62 Sangoi AR, Ohgami RS, Pai RK, Beck AH, McKenney JK and Pai RK: PAX8 expression reliably distinguishes pancreatic welldifferentiated neuroendocrine tumors from ileal and pulmonary well-differentiated neuroendocrine tumors and pancreatic acinar cell carcinoma. Mod Pathol 24(3): 412-424, 2011. PMID: 20890270. DOI: 10.1038/modpathol.2010.176

63 Andersson E, Arvidsson Y, Swärd C, Hofving T, Wängberg B, Kristiansson E and Nilsson O: Expression profiling of small intestinal neuroendocrine tumors identifies subgroups with clinical relevance, prognostic markers and therapeutic targets. Mod Pathol 29(6): 616-629, 2016. PMID: 26965582. DOI: 10.1038/ modpathol.2016.48

64 Cohen PR, Tomson BN, Elkin SK, Marchlik E, Carter JL and Kurzrock R: Genomic portfolio of Merkel cell carcinoma as determined by comprehensive genomic profiling: implications for targeted therapeutics. Oncotarget 7(17): 23454-23467, 2016. PMID: 26981779. DOI: 10.18632/oncotarget.8032

65 Goh G, Walradt T, Markarov V, Blom A, Riaz N, Doumani R, Stafstrom K, Moshiri A, Yelistratova L, Levinsohn J, Chan TA, Nghiem P, Lifton RP and Choi J: Mutational landscape of MCPyV-positive and MCPyV-negative Merkel cell carcinomas with implications for immunotherapy. Oncotarget 7(3): 34033415, 2016. PMID: 26655088. DOI: 10.18632/oncotarget.6494

66 Busam KJ, Pulitzer MP, Coit DC, Arcila M, Leng D, Jungbluth AA and Wiesner T: Reduced H3K27me3 expression in Merkel cell polyoma virus-positive tumors. Mod Pathol 30(6): 877-883, 2017. PMID: 28281550. DOI: 10.1038/modpathol.2017.8

67 Pulitzer MP, Brannon AR, Berger MF, Louis P, Scott SN, Jungbluth AA, Coit DG, Brownell I and Busam KJ: Cutaneous squamous and neuroendocrine carcinoma: genetically and immunohistochemically different from Merkel cell carcinoma. Mod Pathol 28(8): 1023-1032, 2015. PMID: 26022453. DOI: 10.1038/modpathol.2015.60

68 Shen P, Jing Y, Zhang R, Cai MC, Ma P, Chen H and Zhuang G: Comprehensive genomic profiling of neuroendocrine bladder cancer pinpoints molecular origin and potential therapeutics. Oncogene 37(22): 3039-3044, 2018. PMID: 29535424. DOI: 10.1038/s41388-018-0192-5

69 Hiroshima K and Mino-Kenudson M: Update on large cell neuroendocrine carcinoma. Transl Lung Cancer Res 6(5): 530539, 2017. PMID: 29114469. DOI: 10.21037/tlcr.2017.06.12

70 Heilmann AM, Subbiah V, Wang K, Sun JX, Elvin JA, Chmielecki J, Sherman SI, Murthy R, Busaidy NL, Subbiah I, Yelensky R, Nangia C, Vergilio JA, Khan SA, Erlich RL, Lipson D, Ross JS, Miller VA, Shah MH, Ali SM and Stephens PJ:
Comprehensive genomic profiling of clinically advanced medullary thyroid carcinoma. Oncology 90(6): 339-346, 2016. PMID: 27207748. DOI: 10.1159/000445978

71 Mohanty SK, Kim SA, DeLair DF, Bose S, Laury AR, Chopra S, Mertens RB and Dhall D: Comparison of metastatic neuroendocrine neoplasms to the breast and primary invasive mammary carcinomas with neuroendocrine differentiation. Mod Pathol 29(8): 788-798, 2016. PMID: 27125358. DOI: 10.1038/modpathol.2016.69

72 Kim J, Lee WJ, Lee SH, Lee KB, Ryu JK, Kim YT, Kim SW, Yoon YB, Hwang JH, Han HS, Woo SM and Park SJ: Clinical features of 20 patients with curatively resected biliary neuroendocrine tumours. Dig Liver Dis 43(12): 965-970, 2011. PMID: 21856258. DOI: 10.1016/j.dld.2011.07.010

73 Ozturk O, Bayraktar Y and Akyol A: Image of the month: a neuroendocrine tumor invading all portal venous system components. Am J Gastroenterol 111(3): 311, 2016. PMID: 27018107. DOI: 10.1038/ajg.2015.308

74 Bergsland E, Roy R, Stephens P, Ross J, Bailey M and Olshen A: Genomic profiling to distinguish poorly differentiated neuroendocrine carcinomas arising in different sites. Journal of Clinical Oncology 34(15_suppl): 4020-4020, 2019. DOI: 10.1200/JCO.2016.34.15_suppl.4020

75 García-Suárez O, García B, Fernández-Vega I, Astudillo A and Quirós LM: Neuroendocrine tumors show altered expression of chondroitin sulfate, glypican 1, glypican 5, and syndecan 2 depending on their differentiation grade. Front Oncol 4: 15, 2014. PMID: 24570896. DOI: 10.3389/fonc.2014.00015

76 Banck MS and Beutler AS: Advances in small bowel neuroendocrine neoplasia. Curr Opin Gastroenterol 30(2): 163167, 2014. PMID: 24441281. DOI: 10.1097/MOG.00000000 00000043

77 Ross JS, Wang K, Elkadi OR, Tarasen A, Foulke L, Sheehan CE, Otto GA, Palmer G, Yelensky R, Lipson D, Chmielecki J, Ali SM, Elvin J, Morosini D, Miller VA and Stephens PJ: Next-generation sequencing reveals frequent consistent genomic alterations in small cell undifferentiated lung cancer. J Clin Pathol 67(9): 772-776, 2014. PMID: 24978188. DOI: 10.1136/jclinpath-2014-202447

78 George J, Saito M, Tsuta K, Iwakawa R, Shiraishi K, Scheel AH, Uchida S, Watanabe SI, Nishikawa R, Noguchi M, Peifer M, Jang SJ, Petersen I, Büttner R, Harris CC, Yokota J, Thomas RK and Kohno T: Genomic amplification of CD274 (PD-L1) in small-cell lung cancer. Clin Cancer Res 23(5): 1220-1226, 2017. PMID: 27620277. DOI: 10.1158/1078-0432.CCR-16-1069

79 Nadal R, Schweizer M, Kryvenko ON, Epstein JI and Eisenberger MA: Small cell carcinoma of the prostate. Nat Rev Urol 11(4): 213-219, 2014. PMID: 24535589. DOI: 10.1038/nrurol.2014.21

80 Jiao Y, Shi C, Edil BH, de Wilde RF, Klimstra DS, Maitra A, Schulick RD, Tang LH, Wolfgang CL, Choti MA, Velculescu VE, Diaz LA Jr, Vogelstein B, Kinzler KW, Hruban RH and Papadopoulos N: DAXX/ATRX, MEN1, and mTOR pathway genes are frequently altered in pancreatic neuroendocrine tumors. Science 331(6021): 1199-1203, 2011. PMID: 21252315. DOI: 10.1126/science. 1200609

81 George J, Lim JS, Jang SJ, Cun Y, Ozretić L, Kong G, Leenders F, Lu X, Fernández-Cuesta L, Bosco G, Müller C, Dahmen I, Jahchan NS, Park KS, Yang D, Karnezis AN, Vaka D, Torres A, Wang MS, Korbel JO, Menon R, Chun SM, Kim D, Wilkerson M, Hayes N, Engelmann D, Pützer B, Bos M, Michels S, Vlasic I, Seidel D, Pinther B, Schaub P, Becker C, Altmüller J, Yokota J, Kohno T, Iwakawa R, Tsuta K, Noguchi M, Muley T, 
Hoffmann H, Schnabel PA, Petersen I, Chen Y, Soltermann A, Tischler V, Choi CM, Kim YH, Massion PP, Zou Y, Jovanovic D, Kontic M, Wright GM, Russell PA, Solomon B, Koch I, Lindner M, Muscarella LA, la Torre A, Field JK, Jakopovic M, Knezevic J, Castaños-Vélez E, Roz L, Pastorino U, Brustugun OT, LundIversen M, Thunnissen E, Köhler J, Schuler M, Botling J, Sandelin M, Sanchez-Cespedes M, Salvesen HB, Achter V, Lang U, Bogus M, Schneider PM, Zander T, Ansén S, Hallek M, Wolf J, Vingron M, Yatabe Y, Travis WD, Nürnberg P, Reinhardt C, Perner S, Heukamp L, Büttner R, Haas SA, Brambilla E, Peifer $\mathrm{M}$, Sage $\mathrm{J}$ and Thomas RK: Comprehensive genomic profiles of small cell lung cancer. Nature 524(7563): 47-53, 2015. PMID: 26168399. DOI: $10.1038 /$ nature 14664

82 Glenn ST, Jones CA, Sexton S, LeVea CM, Caraker SM, Hajduczok G and Gross KW: Conditional deletion of p53 and Rb in the renin-expressing compartment of the pancreas leads to a highly penetrant metastatic pancreatic neuroendocrine carcinoma. Oncogene 33(50): 5706-5715, 2014. PMID: 24292676. DOI: 10.1038/onc.2013.514

83 Reid MD, Akkas G, Basturk O and Adsay V: Mixed adenoneuroendocrine carcinoma of the pancreas. In: Pancreatic neuroendocrine neoplasms: Practical approach to diagnosis, classification, and therapy. La Rosa S and Sessa F (eds.). Cham, Springer International Publishing, pp. 155-165, 2015.

84 Jesinghaus M, Konukiewitz B, Keller G, Kloor M, Steiger K, Reiche M, Penzel R, Endris V, Arsenic R, Hermann G, Stenzinger A, Weichert W, Pfarr N and Klöppel G: Colorectal mixed adenoneuroendocrine carcinomas and neuroendocrine carcinomas are genetically closely related to colorectal adenocarcinomas. Mod Pathol 30(4): 610-619, 2017. PMID: 28059096. DOI: 10.1038/modpathol.2016.220

85 Kleist B and Poetsch M: Neuroendocrine differentiation: The mysterious fellow of colorectal cancer. World J Gastroenterol 21(41): 11740-11747, 2015. PMID: 26556999. DOI: 10.3748/wjg. v21.i41.11740

86 La Rosa S, Sessa F and Uccella S: Mixed neuroendocrinenonneuroendocrine neoplasms (MiNENs): Unifying the concept of a heterogeneous group of neoplasms. Endocr Pathol 27(4): 284-311, 2016. PMID: 27169712. DOI: 10.1007/s12022-0169432-9

87 de Mestier L, Cros J, Neuzillet C, Hentic O, Egal A, Muller N, Bouché O, Cadiot G, Ruszniewski P, Couvelard A and Hammel P: Digestive system mixed neuroendocrine-non-neuroendocrine neoplasms. Neuroendocrinology 105(4): 412-425, 2017. PMID: 28803232. DOI: $10.1159 / 000475527$

88 Pham QD, Mori I and Osamura RY: A case report: Gastric mixed neuroendocrine-nonneuroendocrine neoplasm with aggressive neuroendocrine component. Case Rep Pathol 2017: 9871687, 2017. PMID: 28626594. DOI: $10.1155 / 2017 / 9871687$

89 Cen D, Chen J, Li Z, Zhao J and Cai X: Prognostic significance of cytokeratin 19 expression in pancreatic neuroendocrine tumor: A meta-analysis. PLoS One 12(11): e0187588, 2017. PMID: 29136022. DOI: 10.1371/journal.pone.0187588

90 Klimstra DS, Modlin IR, Coppola D, Lloyd RV and Suster S: The pathologic classification of neuroendocrine tumors: a review of nomenclature, grading, and staging systems. Pancreas 39(6): 707712, 2010. PMID: 20664470. DOI: 10.1097/MPA.0b013 e3181ec124e

91 Scarpa A, Mantovani W, Capelli P, Beghelli S, Boninsegna L, Bettini R, Panzuto F, Pederzoli P, delle Fave G and Falconi M:
Pancreatic endocrine tumors: improved TNM staging and histopathological grading permit a clinically efficient prognostic stratification of patients. Mod Pathol 23(6): 824-833, 2010. PMID: 20305616. DOI: 10.1038/modpathol.2010.58

92 Vicentini C, Fassan M, D’Angelo E, Corbo V, Silvestris N, Nuovo GJ and Scarpa A: Clinical application of microRNA testing in neuroendocrine tumors of the gastrointestinal tract. Molecules 19(2): 2458-2468, 2014. PMID: 24566314. DOI: 10.3390/ molecules 19022458

93 Kerr SE, Schnabel CA, Sullivan PS, Zhang Y, Huang VJ, Erlander MG, Brachtel EF and Dry SM: A 92-gene cancer classifier predicts the site of origin for neuroendocrine tumors. Mod Pathol 27(1): 44-54, 2014. PMID: 23846576. DOI: 10.1038/modpathol. 2013.105

94 Modlin IM, Kidd M, Bodei L, Drozdov I and Aslanian H: The clinical utility of a novel blood-based multi-transcriptome assay for the diagnosis of neuroendocrine tumors of the gastrointestinal tract. Am J Gastroenterol 110(8): 1223-1232, 2015. PMID: 26032155. DOI: 10.1038/ajg.2015.160

95 Mairinger FD, Ting S, Werner R, Walter RF, Hager T, Vollbrecht C, Christoph D, Worm K, Mairinger T, Sheu-Grabellus SY, Theegarten D, Schmid KW and Wohlschlaeger J: Different microRNA expression profiles distinguish subtypes of neuroendocrine tumors of the lung: results of a profiling study. Mod Pathol 27(12): 1632-1640, 2014. PMID: 24875640. DOI: 10.1038/ modpathol.2014.74

96 Lee SW, Lee IS, Cho YK, Park JM, Kim SW, Choi MG, Choi KY, Lee MA, Hong TH, You YK and Jung ES: A case of mixed adenoneuroendocrine carcinoma of the common bile duct: initially diagnosed as cholangiocarcinoma. Korean J Pathol 48(6): 445448, 2014. PMID: 25588638. DOI: 10.4132/KoreanJPathol. 2014.48.6.445

97 Harada K, Sato Y, Ikeda H, Maylee H, Igarashi S, Okamura A, Masuda S and Nakanuma Y: Clinicopathologic study of mixed adenoneuroendocrine carcinomas of hepatobiliary organs. Virchows Arch 460(3): 281-289, 2012. PMID: 22358181. DOI: 10.1007/s00428-012-1212-4

98 Priyanka Akhilesh S, Kamal Sunder Y, Chandralekha T, Samir P and Prasad Kashinath W: Common hepatic duct mixed adenoneuroendocrine carcinoma masquerading as cholangiocarcinoma. Case Rep Gastrointest Med 2016: 4827050, 2016. PMID: 27375908. DOI: 10.1155/2016/4827050

99 Erlander MG, Ma XJ, Kesty NC, Bao L, Salunga R and Schnabel CA: Performance and clinical evaluation of the 92-gene real-time PCR assay for tumor classification. J Mol Diagn 13(5): 493-503, 2011. PMID: 21708287. DOI: 10.1016/j.jmoldx.2011.04.004

100 Le DT, Durham JN, Smith KN, Wang H, Bartlett BR, Aulakh LK, Lu S, Kemberling H, Wilt C, Luber BS, Wong F, Azad NS, Rucki AA, Laheru D, Donehower R, Zaheer A, Fisher GA, Crocenzi TS, Lee JJ, Greten TF, Duffy AG, Ciombor KK, Eyring AD, Lam BH, Joe A, Kang SP, Holdhoff M, Danilova L, Cope L, Meyer C, Zhou S, Goldberg RM, Armstrong DK, Bever KM, Fader AN, Taube J, Housseau F, Spetzler D, Xiao N, Pardoll DM, Papadopoulos N, Kinzler KW, Eshleman JR, Vogelstein B, Anders RA and Diaz LA Jr: Mismatch repair deficiency predicts response of solid tumors to PD-1 blockade. Science 357(6349): 409-413, 2017. PMID: 28596308. DOI: 10.1126/science.aan6733

101 Lu KH, Wood ME, Daniels M, Burke C, Ford J, Kauff ND, Kohlmann W, Lindor NM, Mulvey TM, Robinson L, Rubinstein 
WS, Stoffel EM, Snyder C, Syngal S, Merrill JK, Wollins DS, Hughes KS and American Society of Clinical Oncology: American Society of Clinical Oncology Expert Statement: collection and use of a cancer family history for oncology providers. J Clin Oncol 32(8): 833-840, 2014. PMID: 24493721. DOI: $10.1200 / J C O .2013 .50 .9257$

102 Blocking $\beta$-catenin signalling - a future therapy for pancreatic neuroendocrine tumours? Nat Rev Endocrinol 11: 132, 2015. DOI: $10.1038 /$ nrendo.2014.241

103 Chan DL, Segelov E and Singh S: Everolimus in the management of metastatic neuroendocrine tumours. Therap Adv Gastroenterol 10(1): 132-141, 2017. PMID: 28286565. DOI: 10.1177/ $1756283 X 16674660$

104 Faivre S, Niccoli P, Castellano D, Valle JW, Hammel P, Raoul JL, Vinik A, Van Cutsem E, Bang YJ, Lee SH, Borbath I, LombardBohas C, Metrakos P, Smith D, Chen JS, Ruszniewski P, Seitz JF, Patyna S, Lu DR, Ishak KJ and Raymond E: Sunitinib in pancreatic neuroendocrine tumors: updated progression-free survival and final overall survival from a phase III randomized study. Ann Oncol 28(2): 339-343, 2017. PMID: 27836885. DOI: 10.1093/annonc/mdw561

105 Yao JC, Lombard-Bohas C, Baudin E, Kvols LK, Rougier P, Ruszniewski P, Hoosen S, St Peter J, Haas T, Lebwohl D, Van Cutsem E, Kulke MH, Hobday TJ, O'Dorisio TM, Shah MH, Cadiot G, Luppi G, Posey JA and Wiedenmann B: Daily oral everolimus activity in patients with metastatic pancreatic neuroendocrine tumors after failure of cytotoxic chemotherapy: a phase II trial. J Clin Oncol 28(1): 69-76, 2010. PMID: 19933912. DOI: $10.1200 / J C O .2009 .24 .2669$

106 Yao JC, Shah MH, Ito T, Bohas CL, Wolin EM, Van Cutsem E, Hobday TJ, Okusaka T, Capdevila J, de Vries EG, Tomassetti P, Pavel ME, Hoosen S, Haas T, Lincy J, Lebwohl D, Öberg K and RAD001 in Advanced Neuroendocrine Tumors, Third Trial (RADIANT-3) Study Group: Everolimus for advanced pancreatic neuroendocrine tumors. N Engl J Med 364(6): 514-523, 2011. PMID: 21306238. DOI: 10.1056/NEJMoa1009290

107 Falconi $\mathrm{M}$ and Partelli S: Neuroendocrine tumours in 2016: Defining rules for increasingly personalized treatments. Nat Rev Clin Oncol 14(2): 80-82, 2017. PMID: 27922042. DOI: 10.1038/nrclinonc. 2016.197

108 Hutchinson L: Targeted therapies: Widening the treatment NET. Nat Rev Clin Oncol 14(1): 2-3, 2017. PMID: 27898066. DOI: 10.1038/nrclinonc. 2016.198
109 Capdevila J, Casanovas O, Salazar R, Castellano D, Segura A, Fuster P, Aller J, García-Carbonero R, Jimenez-Fonseca P, Grande $\mathrm{E}$ and Castaño JP: Translational research in neuroendocrine tumors: pitfalls and opportunities. Oncogene 36(14): 1899-1907, 2017. PMID: 27641330. DOI: 10.1038/onc.2016.316

110 Berardi R, Rinaldi S, Torniai M, Morgese F, Partelli S, Caramanti M, Onofri A, Polenta V, Pagliaretta S, Falconi M and Cascinu S: Gastrointestinal neuroendocrine tumors: Searching the optimal treatment strategy - A literature review. Crit Rev Oncol Hematol 98: 264-274, 2016. PMID: 26643525. DOI: 10.1016/j.critrevonc. 2015.11.003

111 Yoo C, Cho H, Song MJ, Hong SM, Kim KP, Chang HM, Chae H, Kim TW, Hong YS, Ryu MH, Kang YK, Kim SC and Ryoo BY: Efficacy and safety of everolimus and sunitinib in patients with gastroenteropancreatic neuroendocrine tumor. Cancer Chemother Pharmacol 79(1): 139-146, 2017. PMID: 27942928. DOI: $10.1007 / \mathrm{s} 00280-016-3215-3$

112 Rabinowits G: Systemic therapy for Merkel cell carcinoma: What's on the horizon? Cancers (Basel) 6(2): 1180-1194, 2014. PMID: 24840048. DOI: 10.3390/cancers6021180

113 Kannan A, Lin Z, Shao Q, Zhao S, Fang B, Moreno MA, Vural E, Stack BC Jr, Suen JY, Kannan K and Gao L: Dual mTOR inhibitor MLN0128 suppresses Merkel cell carcinoma (MCC) xenograft tumor growth. Oncotarget 7(6): 6576-6592, 2016. PMID: 26536665. DOI: 10.18632/oncotarget.5878

114 Dickson I: Pancreatic cancer: PanNETs elude elimination. Nat Rev Gastroenterol Hepatol 13(6): 314-315, 2016. PMID: 27095652. DOI: $10.1038 /$ nrgastro.2016.67

115 Fazio $\mathrm{N}$ and Milione $\mathrm{M}$ : Heterogeneity of grade 3 gastroenteropancreatic neuroendocrine carcinomas: New insights and treatment implications. Cancer Treat Rev 50: 61-67, 2016. PMID: 27636009. DOI: 10.1016/j.ctrv.2016.08.006

116 Sidaway P: Prostate cancer: N-Myc expression drives neuroendocrine disease. Nat Rev Urol 13(12): 695, 2016. PMID: 27779225. DOI: $10.1038 /$ nrurol.2016.218 